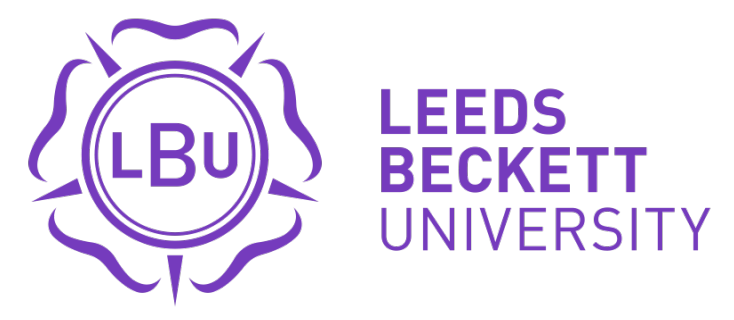

Citation:

O'Mahoney, LL and Alobaid, AM and Ajjan, RA and Birch, KM and Orsi, NM and Mappa, G and Holmes, M and Ho, P and Stavropoulos-Kalinoglou, A and Price, OJ and Campbell, MD (2020) The effect of omega-3 polyunsaturated fatty acid supplementation on vascular structure, function, and inflammation in type 1 diabetes: A double-blind, randomised, placebo-controlled trial. Proceedings of the Nutrition Society, 79 (OCE3). ISSN 0029-6651 DOI: https://doi.org/10.1017/S0029665120007338

Link to Leeds Beckett Repository record:

https://eprints.leedsbeckett.ac.uk/id/eprint/7253/

Document Version:

Article

Published abstract

Copyright (C) The Authors 2020

The aim of the Leeds Beckett Repository is to provide open access to our research, as required by funder policies and permitted by publishers and copyright law.

The Leeds Beckett repository holds a wide range of publications, each of which has been checked for copyright and the relevant embargo period has been applied by the Research Services team.

We operate on a standard take-down policy. If you are the author or publisher of an output and you would like it removed from the repository, please contact us and we will investigate on a case-by-case basis.

Each thesis in the repository has been cleared where necessary by the author for third party copyright. If you would like a thesis to be removed from the repository or believe there is an issue with copyright, please contact us on openaccess@leedsbeckett.ac.uk and we will investigate on a case-by-case basis. 


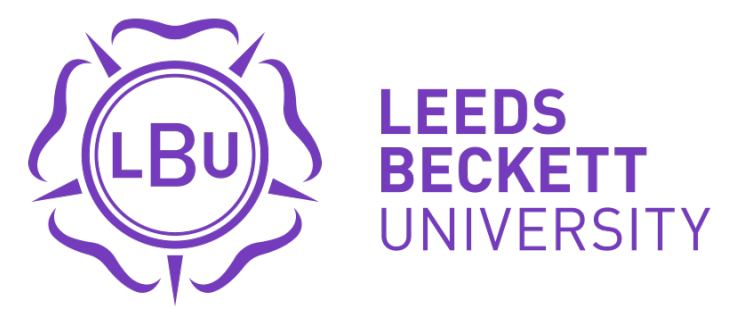

\section{Citation:}

O'Mahoney, LL and Alobaid, AM and Ajjan, RA and Birch, KM and Orsi, NM and Mappa, G and Holmes, M and Ho, P and Stavropoulos-Kalinoglou, A and Price, OJ and Campbell, MD (2020) The effect of omega-3 polyunsaturated fatty acid supplementation on vascular structure, function, and inflammation in type 1 diabetes: A double-blind, randomised, placebo-controlled trial. In: UNSPECIFIED. DOI: https://doi.org/10.1017/S0029665120007338

Link to Leeds Beckett Repository record:

http://eprints.leedsbeckett.ac.uk/id/eprint/7253/

Document Version:

Conference or Workshop Item

The aim of the Leeds Beckett Repository is to provide open access to our research, as required by funder policies and permitted by publishers and copyright law.

The Leeds Beckett repository holds a wide range of publications, each of which has been checked for copyright and the relevant embargo period has been applied by the Research Services team.

We operate on a standard take-down policy. If you are the author or publisher of an output and you would like it removed from the repository, please contact us and we will investigate on a case-by-case basis.

Each thesis in the repository has been cleared where necessary by the author for third party copyright. If you would like a thesis to be removed from the repository or believe there is an issue with copyright, please contact us on openaccess@leedsbeckett.ac.uk and we will investigate on a case-by-case basis. 


\title{
The effect of omega-3 polyunsaturated fatty acid supplementation on vascular structure, function, and inflammation in type 1 diabetes: a double-blind, randomised, placebo-controlled trial
}

\author{
L.L. O’Mahoney ${ }^{1}$, A.M. Alobaid ${ }^{2}$, R.A. Ajjan ${ }^{3}$, K.M. Birch ${ }^{4}$, N.M. Orsi ${ }^{5}$, G. Mappa ${ }^{5}$, \\ M. Holmes ${ }^{2}$, P. Ho ${ }^{2}$, A. Stavropoulos-Kalinoglou ${ }^{1}$, O.J. Price ${ }^{1}$ and M.D. Campbell ${ }^{2}$ \\ ${ }^{1}$ Carnegie School of Sport, Leeds Beckett University, Leeds, UK, \\ ${ }^{2}$ School of Food Science a Nutrition, University of Leeds, Leeds, UK, \\ ${ }^{3}$ School of Medicine, University of Leeds, Leeds, UK, \\ ${ }^{4}$ School of Biomedical Sciences, University of Leeds, Leeds, UK and \\ ${ }^{5}$ Leeds Institute of Cancer \& Pathology, St James's University Hospital, Leeds, UK
}

Raised inflammation and impaired endothelial function are common in patients with type 1 diabetes (T1D) ${ }^{(1-2)}$. Although increased omega-3 polyunsaturated fatty acid (n-3 PUFA) intake can improve risk factors for macrovascular complications in adults with type 2 diabetes $^{(3)}$, such evidence is limited in T1D. Here, we report findings from a trial examining the effect of 6-month n-3 PUFA supplementation on vascular structure, function, and inflammation in adults with T1D.

For this double-blind, randomised, placebo-controlled trial, individuals with T1D ( $\mathrm{n}=20$; males:16; $34 \pm 14$ years; BMI:26.6 \pm 5.2 $\mathrm{kg} / \mathrm{m}^{2}$; glycated haemoglobin $\left.\left(\mathrm{HbA}_{1 \mathrm{c}}\right): 58 \pm 13 \mathrm{mmol} / \mathrm{mol}^{-1}[7.5 \pm 3.3 \%]\right)$, were randomly allocated in a 1:1 ratio to receive either $3.3 \mathrm{~g} /$ day of encapsulated n-3 PUFA or placebo (PLA) consisting of an encapsulated dose of 3.0 g/day corn oil for 6-months. Fatty acids were measured in erythrocyte membranes by gas chromatography with n-3 PUFA index (O3I) calculated as eicosapentaenoic acid plus docosahexaenoic acid. Carotid artery intima-media thickness (CIMT), flow mediated dilation of the brachial artery (FMD), and biomarkers of vascular inflammation were assessed at baseline and following 6-months supplementation. A paired-samples $t$ test was used to compare intragroup mean differences and an independent samples $t$ test was used for comparisons between $n-3$ PUFA and PLA at baseline; statistical significance was set at $\mathrm{p} \leq 0.05$. Data are presented as mean \pm SD.

O3I levels were comparable at baseline, increasing significantly under n-3 PUFA, but not PLA, (mean difference: $3.37 \pm 1.52 \%$ vs. $0.36 \pm 0.69 \% ; p<0.001)$. All outcome variables were similar between conditions at baseline $(p>0.05)$. After 6-months $n-3$ PUFA supplementation, CIMT remained unchanged $(0.61 \pm 0.12 \mathrm{~mm}$ vs. $0.60 \pm 0.10 \mathrm{~mm} ; \mathrm{p}=0.200)$, as did FMD $(7.11 \pm 1.31 \%$ vs. 6.90 $\pm 1.43 \% ; p=0.541)$. Similar findings were observed in the PLA group; CIMT $(0.64 \pm 0.09 \mathrm{~mm}$ vs. $0.64 \pm 0.09 \mathrm{~mm} ; \mathrm{p}=0.726)$ and FMD $(7.66 \pm 1.95 \%$ vs. $7.78 \pm 2.58 \% ; \mathrm{p}=0.656)$. Vascular cell adhesion molecule-1 $(\mathrm{p}=0.825)$, intercellular adhesion molecule-1 $(p=0.926)$, vascular endothelial growth factor $(p=0.332)$, E-selectin $(p=0.420)$, P-selectin $(p=0.390)$, pentraxin-3 $(p=0.902)$, and tumor necrosis factor alpha $(p=0.993)$ remained unchanged in the $n-3$ PUFA group. Comparable findings were observed in the PLA group ( $p>0.05)$. Overall, no safety issues arose during administration of $n-3$ PUFA or PLA.

Despite significant increases in erythrocyte n-3 PUFA concentration, a daily high-dose-bolus of n-3 PUFA for 6-months had no effect on vascular structure, function, or inflammation in adults with T1D. These findings do not support the use of n-3 PUFA supplementation in the management of T1D and its associated macrovascular complications.

1. Jarvisalo MJ, Raitakari M, Toikka JO et al. (2004) Circulation 109, 1750-1755.

2. West DJ, Campbell MD, Gonzalez JT et al. (2015) Cardiovasc Diabetol 14, 1-7.

3. Lobraico JM, DiLello LC, Butler AD et al. (2015) BMJ Open Diabetes Res Care 14, 1-7. 